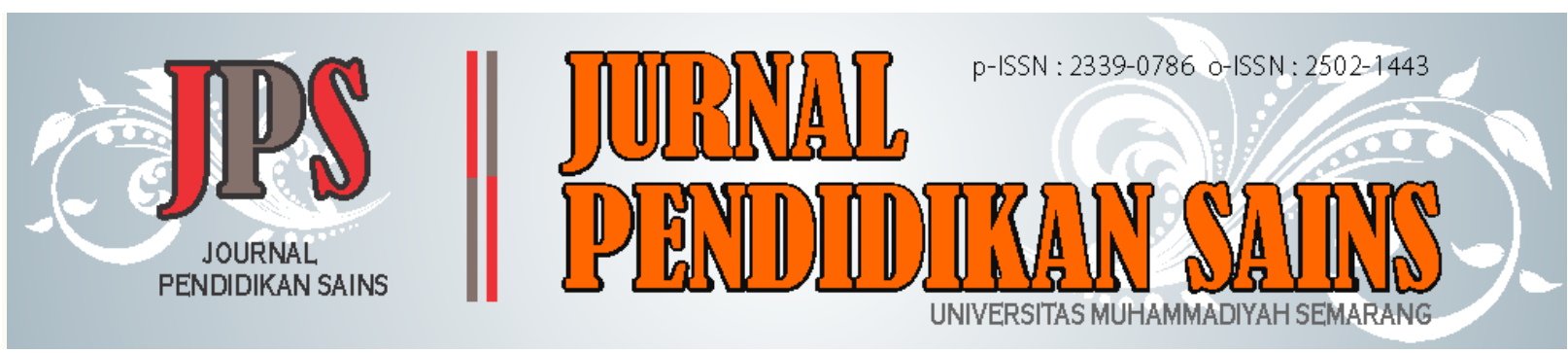

\title{
The Correlation Analysis Between Critical Thinking Skills And Learning Outcomes Through Implementation Of Guided Inquiry Learning Models
}

\author{
Laiaza Aghenia Muhan ${ }^{\mathrm{a}, 1}$, Harun Nasrudin ${ }^{\mathrm{a}, 2, *}$ \\ ${ }^{a}$ Chemistry Education, Universitas Negeri Surabaya, East Java 60231 \\ ${ }^{1}$ laiazaaghenia89@gmail.com ; ${ }^{2}$ harunnasrudin@ unesa.ac.id* \\ * corresponding author
}

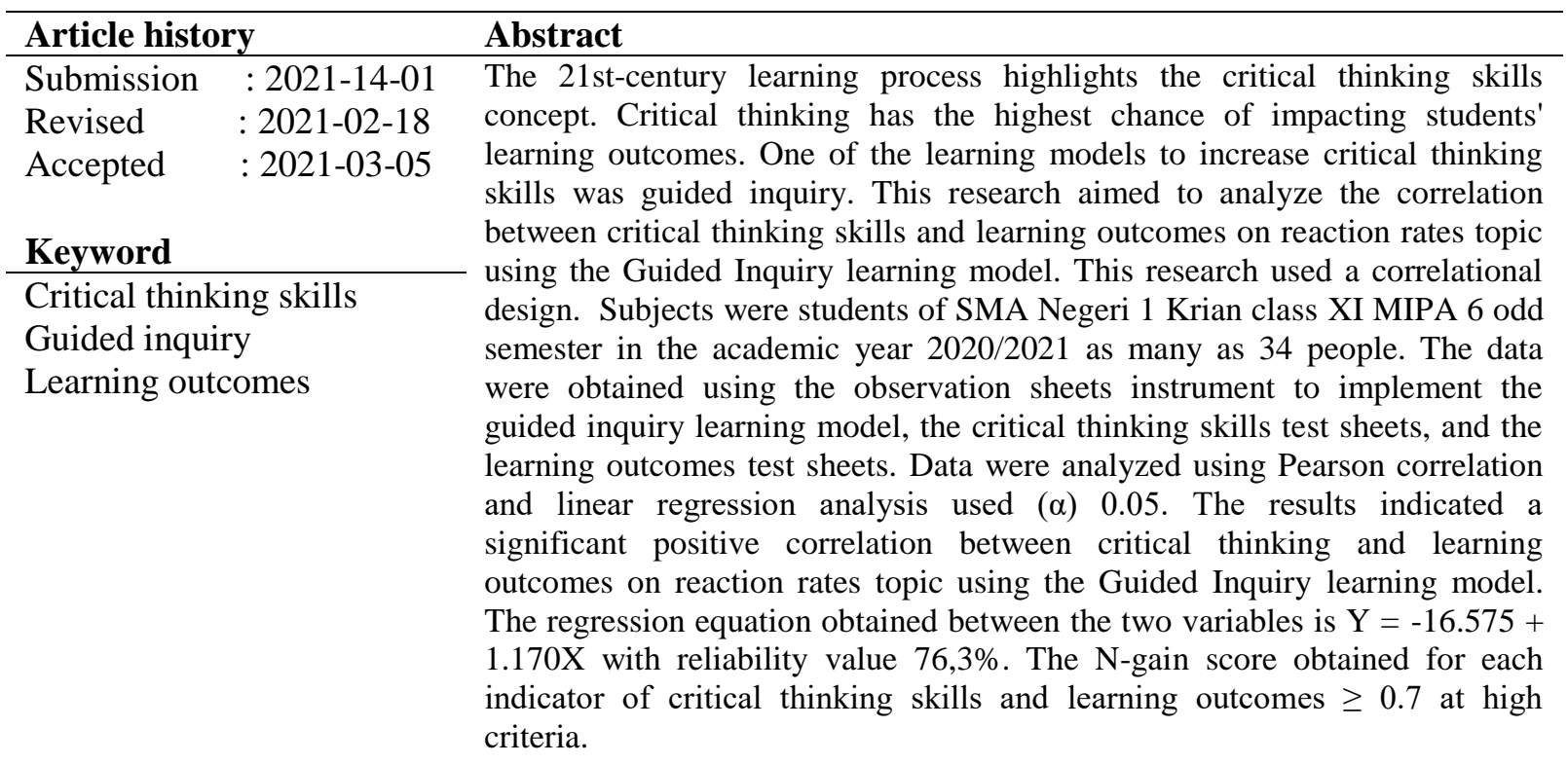

This work is licensed under
a 2021 Jurnal Pendidikan Sains Universitas Muhammadiyah Semarang

\section{INTRODUCTION}

In the Industrial Revolution 4.0, the education sector must prepare students with the four most essential skills in the 21st century known as "Four Cs," which are critical thinking, creativity, collaboration, communication (Redhana, 2019). One of the priorities in the education sector is necessary thinking skills (Frima et al., 2020). In line with Permendikbud No 22 of 2016 concerning Competency Standards for Primary and Secondary Education Graduates, the main goal of education is critical thinking skills, namely thinking logically and rationally about a problem (Permendikbud, 2016).

The concept of critical thinking describes the participation of students in the process of building knowledge through reflection and deep thinking. Curiosity and questioning are characteristics needed from someone who thinks critically because they always try to answer a question or look for evidence to https://jurnal.unimus.ac.id/index.php/JPKIMIA/index 
support claims (Saleh, 2019). Indicators of critical thinking skills include interpretation, analysis, inference, explanation, evaluation, and self-regulation (Facione, 2015).

One of the government's efforts to meet the demands of the $21^{\text {st }}$ century is by implementing the 2013 Curriculum as a refinement of the previous curriculum. Students are required to master all aspects of learning, namely cognitive, affective, and psychomotor aspects. The 2013 curriculum is implemented in Indonesia to develop higher-order thinking skills (HOTS), and critical thinking skills are among the competencies in higher-order thinking skills (Thamrin, N. R. \& Agustin, 2019). Critical thinking is not only an educational goal but also an integral part of education at any level. This is because critical thinking is a thought that analyzes, evaluates, chooses, and provides the best solution for students in solving a problem, especially in academic life (Utami et al., 2017).

Students' critical thinking skills are still low, especially for chemistry subjects, because the learning method still focuses on the teacher as a subject (teacher-centered), resulting in a lack of opportunities for students to actively participate when the learning process is ongoing and affects their critical thinking skills (Oktaviana et al., 2016). Based on a survey on students of class XII MIPA 5, 85\% of students stated that chemistry is complex. Some of the reasons cited include: too many formulas, the material is confusing and less meaningful, the teacher explains only briefly and lacks detail so that students do not understand the material, the learning methods used by the teacher are complex for students to understand, and the learning media only uses books.

This fact is supported by the results of field observations carried out in class XII MIPA 5 through the implementation of the critical thinking skills (CTS) test on the topic of reaction rate on the interpretation indicator $85 \%$ of students have not been able to determine problem formulations, hypotheses, and classify variables. In the analysis indicator, $79 \%$ of students have not been able to provide an accurate analysis. In the Inference indicator, $56 \%$ of students have not been able to make conclusions correctly. On the explanation indicator, as much as $65 \%$ of students have not provided strong arguments.

Learning success is influenced by several factors, namely input, process, and learning outcomes. Information is viewed from the level of critical thinking skills, while the learning process is viewed from the strategies, approaches, and learning models used by the teacher when learning takes place. For indicators of learning success, it can be seen from students' learning outcomes (Andayani, 2018). All parties want to optimize learning outcomes. Therefore logical and critical thinking is needed for raising the progress of learning in the future (Hallatu et al., 2017).

Learning outcomes in the knowledge aspect are used as indicators in evaluating student learning. The factors that influence learning outcomes include critical thinking skills, learning styles, metacognitive skills, and learning models. However, from these various factors, necessary thinking skills have the most significant influence on student learning outcomes, namely, $73.9 \%$ in biology subjects (Mite \& Corebima, 2017). Another study states that critical thinking skills are positively correlated with student learning outcomes (Dehghani et al., 2011).

Specific research related to the correlation between critical thinking skills and learning outcomes based on post-test scores of chemistry subjects, especially reaction rate material, can provide better information about how critical thinking skills correlate with learning outcomes. The research results obtained are significant for the implementation of the learning process and other related research. If the learning model is implemented appropriately, simple linear regression for the relationship between CTS and learning outcomes will be better. The characteristics and advantages of each learning model are different. Therefore, the learning outcomes and simple linear regression equations obtained for each learning model are different.

Critical thinking skills are honed through the learning process (Biber et al., 2013). Guided inquiry is a learning model suitable for improving necessary thinking skills (Murnaka et al., 2019). The choice of the guided inquiry model is also based on the characteristics of the reaction rate material, which is abstract, requiring the ability to understand, memorize, calculate, analyze and conduct experiments (Efliana \& Azhar, 2019).

The guided inquiry model was assessed according to the material characteristics of the reaction rate (Sundari et al., 2017). The guided inquiry model has 5 phases, namely: the confrontation with problems (presenting problems), collecting data from phenomena, collecting data from experiments, organizing and formulating explanations, analyzing the inquiry process (Joyce et al., 2015). Guided 
inquiry learning is a learning activity that is structured in such a way as to involve students in carrying out systematic, logical, critical, and analytical investigations of the problems at hand (Jauhar, 2011).

This statement is supported by research that explains that critical thinking skills can be improved by implementing the guided inquiry model with classical completeness obtained, namely $92.02 \%$, and the $\mathrm{N}$-gain score is in high criteria (Ulya \& Nasrudin, 2019). Other research also states that critical thinking skills have increased by implementing the guided inquiry model with an $\mathrm{N}$-gain score of 0.75 , a high criterion (Hikmah \& Nasrudin, 2016).

Based on this description, it is necessary to research the correlation between critical thinking skills and learning outcomes on the topic of reaction rates by applying the guided inquiry learning model. This study aimed to describe the correlation between necessary thinking skills and learning outcomes on the subject of reaction rates by implementing the guided inquiry model.

\section{METHOD}

\section{Types of Research}

This research is quantitative. The method of this research is descriptive quantitative through correlational analysis. The independent variable (predictor) in this study is critical thinking skills, while the dependent variable (criterion) is learning outcomes.

\section{Time and Place of Research}

The research was conducted in the odd semester of August-October 2020 at SMA Negeri 1 Krian Sidoarjo, East Java.

\section{Research Subject}

The subjects of this study were 34 students of SMA Negeri 1 Krian class XI MIPA 6 odd semester in the academic year 2020/2021.

\section{Research Procedure}

The research is conducted in two stages. First, the preparation stage includes performing a literature study on critical thinking skills, material reaction rates, and the guided inquiry model. Develop learning tools in the form of syllabus, lesson plans, student worksheets, and research instruments, including the observation sheet for the implementation of the guided inquiry model, pre-test and post-test CTS sheets, and learning outcomes. Furthermore, a study and validation of learning tools and research instruments were carried out. While the implementation stages include implementing the pre-test critical thinking skills, the performance of learning using the guided inquiry model twice face to face, followed by post-test critical thinking skills and learning outcomes.

\section{Data Collection Technique}

The data collected are qualitative data and quantitative data. The source of qualitative data is the guided inquiry model compliance sheet. Observation indicators for implementing the learning model include the stages in the syntax of the guided inquiry learning model and take the form of a rating scale (Riduwan, 2015).

The quantitative data in this study came from the CTS pre-test-post-test data in the form of essays and the learning outcomes in multiple-choice. The instrument used has been validated by the validator. Validation includes construct and content in the form of conformity assessment of the observation sheet of learning implementation with guided inquiry syntax, the suitability of item items with learning indicators and CTS indicators to be measured including interpretation, analysis, inference, and explanation, as well as the difficulty level of the questions. The validation results obtained were in the form of a percentage of $90.35 \%$ with perfect criteria.

\section{Data Analysis Technique}

The implementation of the guided inquiry learning model was analyzed using data obtained from the observation sheet of the learning model's feasibility. The following formula calculates the analysis of the percentage of learning implementation:

$$
\% \text { Implementation of Guided Inquiry }=\frac{\text { Total score that obtained }}{\text { Maximum score }} \times 100
$$

Furthermore, the portion obtained is converted to the percentage category table for learning performance (Riduwan, 2015).

Table 1. Percentage Conversion of Learning Implementation

\begin{tabular}{ccc}
\hline No & Percentage $(\%)$ & Criteria \\
\hline 1 & $0-20$ & Very less \\
\hline
\end{tabular}




\begin{tabular}{ccc}
\hline 2 & $21-40$ & Less \\
\hline 3 & $41-60$ & Enough \\
\hline 4 & $61-80$ & Good \\
\hline 5 & $81-100$ & Very good
\end{tabular}

Data analysis used prerequisite tests and hypothesis testing. The prerequisite test is in the form of normality test data pre-test-post-test CTS and learning outcomes. The normality of the Shapiro-Wilk method is used because the data used is less than 50 data (Razali \& Wah, 2011). The linearity test followed them. The linearity test can be seen in the ANOVA Table in the Linearity column. If the significance value is less than 0.05 , the variables tested have a linear relationship (Ghozali, 2016).

Hypothesis testing using the Pearson correlation test and regression test (Tanujaya et al., 2017). The Pearson correlation test aims to prove whether there is a correlation between critical thinking skills and learning outcomes. Data were analyzed using SPSS 23.0.

The last stage was carried out the N-gain test on each CTS indicator studied (interpretation, analysis, inference, and explanation) to determine how much improvement there was after learning using the guided inquiry model. The N-gain test is also used to determine how much improvement in learning outcomes (Nisa et al., 2018). The data used were pre-test and post-test data from the CTS and learning outcomes that had previously been tested for normality by the Shapiro-Wilk method. The N-gain test can be calculated by the following formula (Hake, 1998):

$$
\langle g\rangle=\frac{(\%<S f\rangle-\%<S i>)}{(100 \%-\langle S i>)}
$$

Description: $\langle\mathrm{g}\rangle=$ increase in $\mathrm{CTS} ;\langle\mathrm{Sd}\rangle=$ posttest value; $\langle$ Pretest value

The N-gain score obtained is classified to determine the $\mathrm{N}$-gain criteria. $\mathrm{N}$-gain score $<0.3$ is in the common criterion, $\mathrm{N}$-gain score of $0.3-0.7$ is in the medium criterion, $\mathrm{N}$-gain score $\geq 0.7$ is in the high criterion.

\section{RESULTS AND DISCUSSION}

\section{Learning Implementation Analysis}

Learning implementation analysis aims to describe the implementation of the guided inquiry learning model. Data obtained from observations of the performance of learning two times face to face. Statements are made during the learning process. Observation indicators for implementing the learning model include the phases that exist in the syntax of the guided inquiry learning model. The steps observed were (1) Confrontation with problems, (2) Verification of data collection, (3) Collecting experimental data, (4) Organizing, formulating explanations, and (5) Analysis of the investigation process as presented in Figure 1.

\section{Graphic of Guided Inquiry Learning Implementation}

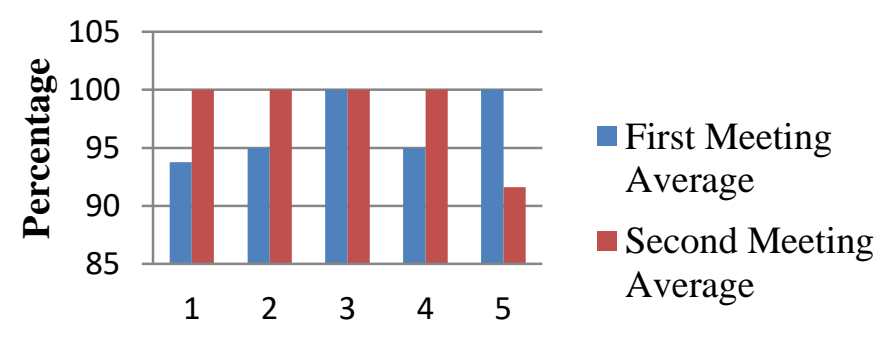

Guided Inquiry Phases

Figure 1. Graphic of Guided Inquiry Learning Implementation

Based on Figure 1, the implementation of learning through the performance of the guided inquiry learning model is in the outstanding category with a percentage of each phase $\geq 61 \%$ and an average percentage of $96.75 \%$ at the first meeting and the second meeting an average percentage of $98.32 \%$. This finding follows the results of previous research that the implementation of the guided inquiry learning model on chemistry matter is in the excellent category (Fadlilah \& Nasrudin, 2020).

In phases, 1 to 3 , namely confrontation with problems, verification of data collection, and experimental data collection processes, trained critical thinking skills are interpretation indicators. In the 
first phase, students are asked to formulate problems based on the phenomena shown. In the second phase, students are requested to verify issues by formulating hypotheses or provisional assumptions; in the third phase, students are asked to classify relevant variables and causal test relationships through experiments.

In the fourth phase, students were asked to organize the data obtained in tables and graphs and analyze the relationship between variables to improve their critical thinking skills on analysis indicators. After that, students are asked to conclude the results of the analysis. It is in this phase that the inference indicator is trained. In the fifth phase, students are asked to present the results of their experiments in the form of solid arguments. This phase trains critical thinking skills on explanatory indicators.

The next stage is the correlation analysis between the CTS and learning outcomes. The research data used were the results of the CTS post-test and the post-test offshoots of understanding the topic of reaction rates with the implementation of the guided inquiry model. Before the correlation test was carried out, the data obtained had to pass the Shapiro-Wilk \& Linearity test for normality.

\section{Prerequisite Test}

\section{a. Normality test}

The purpose of the normality test is to test whether a variable is normally distributed or not. If the significance value obtained is more than 0.05 , then the data is normally distributed (Ghozali, 2016). The methods that state the best average distribution results for data totaling less than 50 are the Shapiro-Wilk method, Lilliefors, and Kolmogorov-Smirnov methods. The results of the Shapiro Wilk CTS normality test and learning outcomes are shown in Table 2.

Table 2. Shapiro-Wilk Normality Test Results

\begin{tabular}{lccc}
\hline & \multicolumn{3}{c}{ Shapiro-Wilk } \\
\hline & Statistics & df & Sig. \\
\hline $\begin{array}{l}\text { Critical } \\
\text { Thinking Skills }\end{array}$ & .967 & 34 & .382 \\
\hline $\begin{array}{l}\text { Learning } \\
\text { outcomes }\end{array}$ & .938 & 34 & .056 \\
\hline
\end{tabular}

Based on the normality test, a significance value of 0.382 was obtained in the critical thinking skills data, while a significance value of 0.056 was obtained for the learning outcome data. Both variables show a significance value $>0.05$, which indicates that the CTS data and learning outcomes are normally distributed.

\section{b. Linearity Test}

The purpose of the linearity test is to test whether there is a significant linear relationship between CTS and learning outcomes (Sugiyono \& Susanto, 2015), as presented in Table 3.

Table 3. Linearity Test Results

\begin{tabular}{|c|c|c|c|c|c|c|c|}
\hline & & & $\begin{array}{l}\text { Sum of } \\
\text { Squares }\end{array}$ & Df & $\begin{array}{l}\text { Mean } \\
\text { Square }\end{array}$ & $\mathrm{F}$ & Sig. \\
\hline \multirow{5}{*}{$\begin{array}{l}\text { Learning } \\
\text { Outcomes * } \\
\text { Critical Thinking } \\
\text { Skills }\end{array}$} & \multirow[t]{3}{*}{$\begin{array}{l}\text { Between } \\
\text { Groups }\end{array}$} & (Combined) & 1664.488 & 7 & 237.784 & $\begin{array}{r}13.04 \\
1 \\
\end{array}$ & .000 \\
\hline & & Linearity & 1632.676 & 1 & 1632.676 & $\begin{array}{r}89.54 \\
2 \\
\end{array}$ & .000 \\
\hline & & $\begin{array}{l}\text { Deviation from } \\
\text { Linearity }\end{array}$ & 31.812 & 6 & 5.302 & .291 & .936 \\
\hline & \multicolumn{2}{|c|}{ Within Groups } & 474.074 & 26 & 18.234 & & \\
\hline & \multicolumn{2}{|l|}{ Total } & 2138.562 & 33 & & & \\
\hline
\end{tabular}

According to Ghozali (2016), data is said to have a linear relationship if the significance value obtained is less than 0.05 . It can be seen in Table 3 that the significant value in the linearity column for critical thinking skills is $0.000<0.05$, which indicates a linear relationship between critical thinking skills and learning outcomes.

\section{Hypothesis Test}

The purpose of hypothesis testing is to test whether or not there is a correlation between CTS and learning outcomes on the topic of reaction rates by implementing the guided inquiry learning model. The https://jurnal.unimus.ac.id/index.php/JPKIMIA/index 
hypothesis test used is the Pearson correlation test and regression using SPSS 23 with a significance level of 0.05 .

\section{a. Pearson Correlation Test}

The Pearson Correlation test was conducted to measure how strong the linear relationship between variables was viewed from the correlation coefficient (Siregar, 2013).

Table 4. Pearson Correlation Test Results of CTS and Learning Outcomes

\begin{tabular}{llrrr}
\hline & & & & \multicolumn{2}{c}{$\begin{array}{c}\text { Learning } \\
\text { Outcomes }\end{array}$} \\
\hline Critical Thinking Skills & Pearson Correlation & 1 & $.874^{* *}$ \\
\cline { 2 - 5 } & Sig. (2-tailed) & 34 & .000 \\
\cline { 2 - 5 } & $\mathrm{N}$ & $.874^{* * *}$ & 34 \\
\hline Learning Outcomes & Pearson Correlation & .000 & 1 \\
\cline { 2 - 5 } & Sig. (2-tailed) & 34 & 34 \\
\cline { 2 - 5 } & $\mathrm{N}$ & & 14 & 34 \\
\end{tabular}

Table 4 shows that critical thinking skills with learning outcomes prove the value of the Pearson correlation or correlation coefficient of $0.874 * *$. This value is then interpreted in the correlation criteria according to Sugiyono (2015) and is included in the powerful correlation category. The correlation coefficient obtained is positive, which indicates that critical thinking skills have a positive correlation with learning outcomes. It can be concluded that the implementation of the guided inquiry learning model on the topic of reaction rates can improve CTS and learning outcomes.

\section{b. Regression Test}

The first stage was to analyze the data using the ANOVA test to determine whether the predictor (critical thinking skills) can predict the criteria (learning outcomes) significantly with $(\alpha) 0.05$. The regression model is said to be linear if the sig. $<0.05$.

Table 5. ANOVA

\begin{tabular}{llrrrrr}
\hline Model & & Sum of & & & & \\
Squares & \multicolumn{1}{c}{ Df } & Mean Square & F & \multicolumn{1}{c}{ Sig. } \\
\hline 1 & Regression & 1632.676 & 1 & 1632.676 & 103.275 & $.000^{b}$ \\
\cline { 2 - 7 } & Residual & 505.886 & 32 & 15.809 & & \\
\cline { 2 - 7 } & Total & 2138.562 & 33 & & & \\
\hline
\end{tabular}

a. Dependent Variable: Learning Outcomes

b. Predictors: (Constant), Critical Thinking Skills

Based on Table 5, the Sig. 0,000 or less than $(\alpha)$, which is 0.05 . The conclusion is that $\mathrm{H} 0$ is rejected because of the sig. $0.000<0.05$, which proves a relationship between CTS and learning outcomes on the topic of reaction rates through the implementation of the guided inquiry learning model. Furthermore, a regression analysis was carried out to determine the mathematical equations that could show the relationship between CTS and learning outcomes on the topic of reaction rates by applying guided inquiry learning.

Table 6. Model Summary

\begin{tabular}{|c|c|c|c|c|c|}
\hline Model & $\mathrm{R}$ & R Square & $\begin{array}{l}\text { Adjusted R } \\
\text { Square }\end{array}$ & $\begin{array}{l}\text { Std. The } \\
\text { error of the } \\
\text { Estimate }\end{array}$ & $\begin{array}{l}\text { Durbin- } \\
\text { Watson }\end{array}$ \\
\hline 1 & $.874^{\mathrm{a}}$ & .763 & .756 & 3.97605 & 2.447 \\
\hline \multicolumn{6}{|c|}{ a. Predictors: (Constant), Critical Thinking Skills } \\
\hline \multicolumn{6}{|c|}{ b. Dependent Variable: Learning Outcomes } \\
\hline
\end{tabular}

In Table 6, the R-value (correlation coefficient) is 0.874 , which proves a robust correlation between CTS and learning outcomes. Also, the $\mathrm{R}$ square value (coefficient of determination simultaneously) was obtained as 0.763 . These results explain that the CTS affects got $76.3 \%$ on learning outcomes, and the remaining $23.7 \%$ is influenced by other variables that were not tested in this study. The next step is to calculate the correlation regression equation, which aims to test the linearity of the correlation.

Table 7. Regression Equations 


\begin{tabular}{ccccccc}
\hline & & $\begin{array}{c}\text { Unstandardized } \\
\text { Coefficients }\end{array}$ & \multicolumn{3}{c}{$\begin{array}{c}\text { Standardized } \\
\text { Coefficients }\end{array}$} \\
\hline Model & & B & Std. Error & Beta & T & Sig. \\
\hline 1 & (Constant) & -16.575 & 10.028 & & -1.653 & .108 \\
\hline & Critical & 1.170 & .115 & .874 & 10.162 & .000 \\
& Thinking Skills & & & & & \\
\hline
\end{tabular}

a. Dependent Variable: Learning Outcomes

The simple regression equation has the formula $\mathrm{Y}=\mathrm{a}+\mathrm{bX}$. The value of "a" is a constant number of unstandardized coefficients, which is $-16,575$. This indicates that if there are no critical thinking skills, the consistent value of learning outcomes is $-16,575$. The value " $b "$ is the regression efficiency figure, which is equal to 1,170 . This means that with every $1 \%$ addition of critical thinking skills, learning outcomes will increase by 1,170 . Based on these data and descriptions, the regression equation $\mathrm{Y}=-16.575+1.170 \mathrm{X}$ is obtained. Based on the regression equation obtained, it can be presented in the following correlation curve.

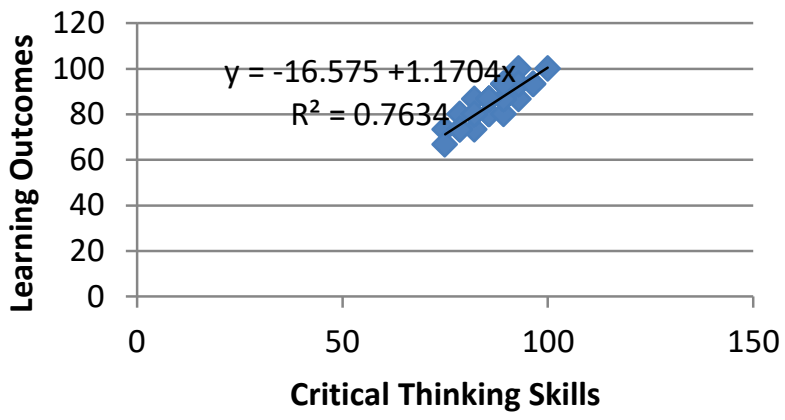

Figure 2. Correlation Curve based on the Regression Equation

On this curve, the regression equation $\mathrm{Y}=-16.575+1.170 \mathrm{X}$ is obtained. Student learning outcomes will increase in proportion to the increase in critical thinking skills. There is a strong positive correlation between CTS and learning outcomes due to the suitability of the guided inquiry model applied at the time of learning. The findings of this study agree with the results of Mite \& Yakobi's research, which states that critical thinking skills have the greatest influence on student learning outcomes, which is 73.9\% (Mite \& Corebima, 2017). This statement is supported by other research that states that critical thinking skills are positively correlated with learning outcomes (Dehghani et al., 2011).

\section{$\mathrm{N}$-gain Test}

The purpose of conducting the N-gain test is to test the extent to which the improvement of critical thinking skills is on each of the indicators studied, namely: interpretation, analysis, inference, and explanation. The data used are in the form of the pre-test, and post-test values for the CTS tested for normality.

Table 8. Normality Test of Pretest and Posttest of Critical Thinking Skills

\begin{tabular}{cccc}
\hline & \multicolumn{3}{c}{ Shapiro-Wilk } \\
\hline & Statistic & Df & Sig. \\
\hline $\begin{array}{c}\text { Pre Test } \text { Critical } \\
\text { Thinking Skills }\end{array}$ & .938 & 34 & .055 \\
\hline $\begin{array}{c}\text { Post Test Critical } \\
\text { Thinking Skills }\end{array}$ & .967 & 34 & .382 \\
\hline
\end{tabular}

In Table 8, the CTS pre-test and post-test results are normally distributed, as evidenced by the sig. $>0.05$. For the pre-test, the sig. Obtained is 0.055 , while the post-test is 0.382 . Then the N-gain score is calculated for each critical thinking skills indicator using the N-gain formula (Hake, 1998).

Table 9. N-Gain Score for Each Indicator of Critical Thinking Skills

\begin{tabular}{ccc}
\hline CTS indicators & N-Gain Score & Criteria \\
\hline Interpretation & 0,7 & High \\
\hline Analysis & 0,9 & High \\
\hline
\end{tabular}




\begin{tabular}{ccc}
\hline Inference & 1,0 & High \\
\hline Explanation & 0,9 & High \\
\hline
\end{tabular}

Table 9 shows the N-Gain score obtained for each CTS indicator $\geq 0.7$ and is at a high criterion which proves an increase in critical thinking skills for each indicator by implementing the guided inquiry model. This is because the guided inquiry model focuses more on and maximizes the participation of students when researching something, meaning that in this learning, students are positioned as subjects and not learning objects that are more teacher-centered like conventional learning (Al-Tabany, 2014).

In addition, the learning outcomes of students also showed a significant increase, as evidenced by the pre-test average score of 35.29 and the post-test average score of 85.09, so that the N-gain score was 0.7. high criteria. This finding follows the research results by Ulya (2019), which states that learning using the guided inquiry model is appropriate when implemented for chemistry learning, especially on the topic of reaction rates. In addition, guided inquiry can improve critical thinking skills and learning outcomes very well, as evidenced by the $\mathrm{N}$-gain score obtained, which is at a high criterion. The results of this study are by the findings of Sutoyo et al. (2019) regarding the effectiveness of the guided inquiry model to improve the student's critical thinking skills in chemistry learning (Sutoyo et al., 2019).

\section{CONCLUSION}

Based on the results and discussion, it can be concluded that there is a powerful and significant positive correlation between critical thinking skills and learning outcomes on the topic of reaction rates through the implementation of the guided inquiry model. The critical thinking skills affects got $76.3 \%$ on learning outcomes, and the remaining $23.7 \%$ is influenced by other variables that were not tested in this study.

\section{ACKNOWLEDGMENT}

The author would like to thank the lecturers of the S1 Chemistry Education Study Program, especially Prof. Dr. Harun Nasrudin, M.S. as the supervisor, and Dr. Sukarmin, M.Pd. as head of the Department of Chemistry, Faculty of Mathematics and Natural Sciences, the State University of Surabaya for the support that has been given to complete this research. The author also thanks the SMA Negeri 1 Krian for the support and assistance provided during the research implementation.

\section{REFERENCES}

Al-Tabany, T. I. . (2014). Mendesain Model Pembelajaran Inovatif, Progresif, dan Kontekstual. Prenamedia Group.

Andayani, Y. (2018). The Correlation of Prospective Teachers' Tendency of Critical Thinking and Their Critical Thinking Skills Towards Their Learning Outcomes. Unnes Science Education Journal, 7(2), 229-233. https://doi.org/10.15294/usej.v7i2.23226

Biber, A., Abdulkadir, T., \& Lutfi., I. (2013). An investigation of critical thinking dispositions of mathematics teacher candidates. Educational Research, 4(4), 109-117.

Dehghani, M., Sani, H. J., Pakmehr, H., \& Malekzadeh, A. (2011). Relationship Between Student's Critical Thinking and Self-Efficacy Beliefs in Ferdowsi University of Mashhad Iran. Procedia Social and Behavioral Science, 15, 2952-2955.

Efliana, R., \& Azhar, M. (2019). Pengembangan Lembar Kerja Peserta Didik (LKPD) Laju Reaksi Berbasis Inkuiri Terstruktur Kelas XI SMA. Edukimia Journal, 1(2), 53-60.

Facione, P. . (2015). Critical Thinking: What It Is and Why It CountsCritical Thinking: What It Is and Why It Counts. Measured Reasons LLC.

Fadlilah, A., \& Nasrudin, H. (2020). Implementation of Inquiry Learning Models Integrated with Nested to Increase Student's Critical Thinking Skill on Electrolyte and Non-Electrolyte Solution Materials. Journal of Chemistry Education Research, 4(2), 83-92.

Frima, F. K., Gumilar, G. G., \& Supriyant, F. T. (2020). Pengaruh Metode Discovery-Inquiry Terhadap Profil Keterampilan Berpikir Kritis Siswa Pada Pembelajaran Topik Kelarutan. Jurnal Pendidikan Sains (JPS), 8(1), 41-49.

Ghozali, I. (2016). Aplikasi Analisis Multivariate dengan Program IBM SPSS 23 (8th ed.). BPFE Universitas Diponegoro.

Hake, R. R. (1998). Interactive engagement versus traditional methods: A six-thousand-student survey of mechanics tests data for introductory physics courses. American Journal of Physics, 66(1), 64-74.

https://jurnal.unimus.ac.id/index.php/JPKIMIA/index 
Hallatu, Y., Prasetyo, K., \& Haidar, A. (2017). Pengaruh Model Problem Based Learning Terhadap Kompetensi Pengetahuan dan Ketrampilan Berpikir Kritis Siswa Madrasah Aliyah BPD Iha Tentang Konflik. Jurnal Penelitian Pendidikan, 34(2), 183-190.

Hikmah, A., \& Nasrudin, H. (2016). Implementation of Guided Inquiry Learning Model to Practice Critical Thinking Skill on Chemical Equilibrium Material at SMA Negeri 1 Probolinggo. Unesa Journal of Chemical Education, 5(1), 155-166.

Jauhar, M. (2011). Implementasi Paikem dari Behavioristik sampai konstruktivistik. Pustakaraya.

Joyce, B., Weil, M., \& Calhoun, E. (2015). Models of Teaching (9th ed.). Pustaka Pelajar.

Mite, Y., \& Corebima, D. A. (2017). The Correlation Between Critical Thinking and The Learning Results of The Senior High School Students in Biology Learning Implementing Group Investigation (GI) Learning in Malang, Indonesia. Journal of Applied and Advanced Research, 2(2), 56-62. https://doi.org/10.21839/jaar.2017.v2i2.57

Murnaka, N. P., Almaisurie, Q., \& Arifin, S. (2019). Method On Guided Inquiry Learning To Improve Students' Critical Thinking Abilities In Facing The Industrial Revolution 4.0. INTERNATIONAL JOURNAL OF SCIENTIFIC \& TECHNOLOGY RESEARCH, 8(9).

Nisa, E. K., Koestiari, T., Habibbulloh, M., \& Jatmiko, B. (2018). Effectiveness of guided inquiry learning model to improve students' critical thinking skills at senior high school. Journal of Physics: Conference Series, 997(1), 12-49.

Oktaviana, I. A., S, A. N. C., \& Utami, B. (2016). Upaya Peningkatkan Kemampuan Berpikir Kritis Dan Prestasi Belajar Siswa Melalui Penerapan Model Pembelajaran Problem Based Learning (Pbl) Dilengkapi Modul Pada Materi Kelarutan Dan Hasil Kali Kelarutan Kelas Xi Sma Negeri 1 Gondang Tahun Pelajaran 2014/20. Jurnal Pendidikan Kimia (JPK), 5(1), 143-152.

Permendikbud. (2016). Permendikbud Nomor 22 Tentang Standart Kompetensi Lulusan Pendidikan Dasar dan Menengah. Kementrian Pendidikan dan Kebudayaan.

Razali, N. M., \& Wah, Y. B. (2011). Normalization of the Kolmogorov-Smirnov, and Shapiro-Wilk tests of normality. Journal of Statistical Modeling and Analytics, 2(1), 21-33. https://doi.org/10.1515/bile-2015-0008

Redhana, I. W. (2019). Mengembangkan Keterampilan Abad Ke-21 dalam Pembelajaran Kimia. Jurnal Inovasi Pendidikan Kimia, 13(1), 2239-2253.

Riduwan. (2015). Dasar-Dasar Statistika. Alfabeta.

Saleh, S. E. (2019). Critical thinking as a 21 st Century Skill: Conceptions, Implementation, and Challenges in the EFL Classroom. European Journal of Foreign Language, 4(1), 1-16. https://doi.org/10.5281/zenodo.2542838

Siregar, S. (2013). Statistik Parametrik untuk Penelitian Kualitatif. Bumi Aksara.

Sugiyono, \& Susanto, A. (2015). Cara Mudah Belajar SPSS \& Lisrel. CV. Alfabeta.

Sundari, T., Pursitasari, I. D., \& Heliawati, L. (2017). Pembelajaran inkuiri terbimbing berbasis praktikum pada topik laju reaksi. Pendidikan Sains Pascasarjana Universitas Negeri Surabaya, 6(2), 1340-1347.

Sutoyo, S., Azizah, U., \& Allamin, S. (2019). Effectiveness of the Guided Inquiry Model Integrated with STEM to Improve the Student Critical Thinking Skills in Chemistry Learning. International Journal of Innovative Science and Research Technology, 4(12), 349-353.

Tanujaya, B., Mumu, J., \& Margono, G. (2017). The Relationship between Higher Order Thinking Skills and Academic Performance of Student in Mathematics Instruction. International Education Studies, 10(11), 78-85.

Thamrin, N. R., \& Agustin, S. (2019). Conceptual Variations on Reading Comprehension Through Higher Order Thinking Skills (HOTS) Strategy. English Review: Journal of English Education, 7(2), 93-100.

Ulya, L. T., \& Nasrudin, H. (2019). Penerapan Model Pembelajaran Guided Inquiry Untuk Melatihkan Keterampilan Berpikir Kritis Peserta Didik Pada Materi Laju Reaksi Kelas XI MAN 1 Tuban. Unesa Journal of Chemical Education, 8(3), 327-331.

Utami, B., Saputro, S., Masykuri, M., \& Widoretno, S. (2017). Critical thinking skills profile of high school students in learning chemistry. International Journal of Science and Applied Science: Conference Series, 1(2), 124-130. https://doi.org/10.20961/ijsascs.v1i2.5134 